\title{
Comparative morphological and molecular studies on Myxobolus spp. infecting chub from the River Danube, Hungary, and description of M. muellericus sp. $\mathbf{n}$.
}

\author{
K. Molnár*, Sz. Marton, E. Eszterbauer, Cs. Székely \\ Veterinary Medical Research Institute, Hungarian Academy of Sciences, PO Box 18, 1581 Budapest, Hungary
}

\begin{abstract}
During a survey on fishes from the River Danube, the occurrence of 8 Myxobolus species (Myxozoa: Myxobolidae) was registered in chub Leuciscus cephalus L. Most species had a specific location within the fish host. M. cycloides was found in the wall of the swimbladder; the branched plasmodia of $M$. dujardini were located typically in the epithelium of the non-lamellar part of gill filaments; the plasmodia of $M$. ellipsoides infected fins between 2 fin rays; $M$. muelleri and Myxobolus sp. 2 formed large elongated plasmodia in the afferent gill artery of filaments, while the round cysts of $M$. muellericus sp. n. filled the capillary network of the gill lamellae. Intramuscular plasmodia of M. pseudodispar proved to be the most common, although large cysts of Myxobolus sp. 1 were also frequently found in the intestinal wall. Despite similarities of some species in spore morphology, 18S rDNA sequences showed clear differences between the species examined.
\end{abstract}

KEY WORDS: Myxozoa $\cdot$ Occurrence $\cdot$ Histology $\cdot$ Site selection $\cdot$ Molecular phylogeny

\section{INTRODUCTION}

The European chub Leuciscus cephalus (L.) is one of the most common fish in Europe and in the Middle East. Several papers have been published on the parasitic infection of this fish and its subspecies. Of Мухоbolus spp. originally described from chub, Landsberg \& Lom (1991) and Eiras et al. (2005) recorded 5 species [M. infundibulatus Donec et Kulakovskaya, 1962; $M$. isakovi Shaova, 1962; M. cabedae (Ghittino, 1962); $M$. leuciscini Gonzales-Lanza et Alvarez-Pellitero, 1985; M. muelleri Bütschli, 1882], but Donec \& Shulman (1984) suggested that further species [Myxobolus cycloides Gurley, 1893; M. dujardini (Thélohan, 1892); M. ellipsoides Thélohan, 1892; M. pseudodispar Gorbunova, 1936], described from other cyprinids of the subfamily Leuciscinae, might belong to the parasite fauna of chub. Data presented by different authors on the occurrence of Myxobolus spp. in chub are based on unreliable identifications of spores (Shulman 1962,
1966), and only a few papers have dealt with the vegetative developmental stages, intrapiscine location, development and pathology of these parasites (Lom \& Dyková 1992, 1995, Kent et al. 2001). Holzer \& Schachner (2001) reported the occurrence of 6 Myxozoa, among them 4 Myxobolus spp. in chub, but they examined only M. cyprini Doflein, 1898 in detail. Reliable data on Myxobolus spp. infecting chub are available for 3 species. Lom (1961) recorded the frequent occurrence of M. dujardini in L. cephalus and L. leuciscus, while Holzer \& Schachner (2002) described intensive infection of the swimbladder of chub with $M$. cycloides. Both of the 2 species above have been described from Rutilus rutilus, another leuciscine fish that is closely related to chub. A third species, $M$. buckei, was recently described by Longshaw et al. (2003) from the spinal column of chub, but this species has also been found in roach and common bream. The host specificity of Myxobolus spp. has been less frequently studied. These species include parasites with a 


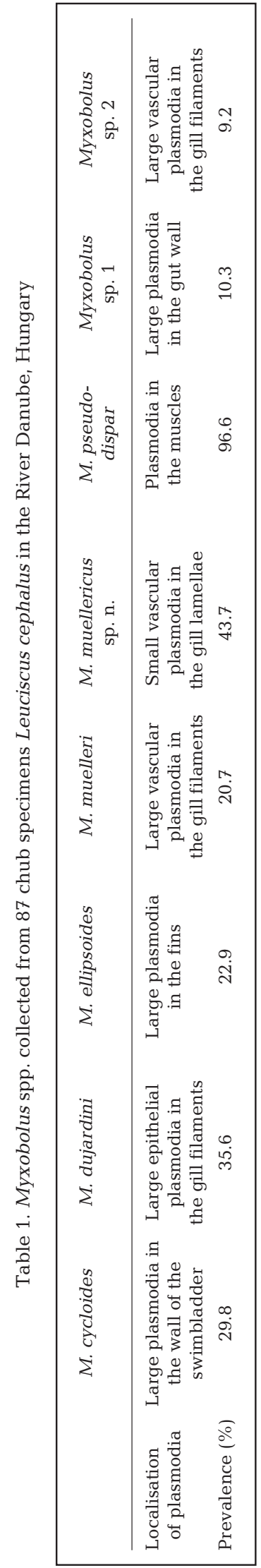

relatively strict host specificity, such as $M$. drjagini Achmerov, 1954, which forms plasmodia only in Hypophthalmichthys molitrix and does not develop in its closely related cyprinid species, $H$. nobilis. On the other hand, M. cerebralis Hofer, 1903 has a wide host range and infects several salmonid fishes (Hoffman 1999), although experiments performed by El-Matbouli et al. (1999) proved that there were important differences in the susceptibility of different salmonids to $M$. cerebralis. Moreover, the lake trout Salvelinus namaycush seems to be resistant to $M$. cerebralis, as has been reported by Blazer et al. (2004) on the basis of in vivo experiments.

Similarly, little is known about the affinity to different fish tissues of Myxobolus spp. infecting chub. For M. cycloides infection, Holzer \& Schachner (2002) reported a special swimbladder location. Molnár (1994) suggested that most myxozoans had a well-defined tissue and organ specificity. The variations of locations in gills and fins, and the tissue preferences of different Myxobolus species were summarised by Molnár (2002a,b). This author differentiated developments in the gill arch, gill filaments and gill lamellae as locations typical of different species. Gill-infecting Мухоbolus spp. from cyprinids in Hungary were also studied by molecular biological methods. The phylogenetic positions of Myxobolus species examined showed that there was a correlation between site preference and the genetic relationships among Myxobolus species (Eszterbauer 2004).

Our paper presents data on the spore morphology and molecular biology of 8 Myxobolus species found in chub, on the typical locations of infection and the histological changes caused by it. In addition, the authors describe $M$. muellericus sp. $\mathrm{n}$. on the basis of molecular biological findings and the location of plasmodia within fish host.

\section{MATERIALS AND METHODS}

The myxozoan fauna of chub Leuciscus cephalus was studied in the River Danube and in its tributary creeks in Szentendre, north of Budapest, between 1998 and 2005.
Altogether 87 specimens of 1 and 2 yr old fish, 6 to $18 \mathrm{~cm}$ long, were seined or collected using an electrofishery device (Table 1). Fish were carried to the laboratory alive, in oxygenated plastic bags, kept in aerated aquaria and subjected to complete parasitological dissection within $3 \mathrm{~d}$.

When mature plasmodia were found, some of the spores were studied in fresh preparations, some of them were collected in Eppendorf tubes and stored at $-20^{\circ} \mathrm{C}$ until further molecular use, while the rest of the spores were preserved in glycerinegelatine as slide preparations or used for transmission experiments. Tissue samples from infected organs containing developing and mature plasmodia were fixed in Bouin's solution, embedded in paraffin wax, cut to 4-5 $\mu \mathrm{m}$ sections, and stained with haematoxylin and eosin. The vitality of spores was checked by adding spores into a $0.4 \%$ solution of urea. Spores of a given plasmodium were regarded as mature when at least $90 \%$ of the spores extruded polar filaments in this solution. Unfixed spores were studied using Nomarski differential interference contrast with an Olympus BH2 microscope. The spores were photographed with an Olympus DP10 digital camera or recorded on videotapes; digitised images were obtained and measurements were taken with the IMAGO ${ }^{\circledR}$ software. All measurements are given in $\mu \mathrm{m}$.

Molecular methods. For DNA extraction, samples were centrifuged at $5000 \times g$ for $5 \mathrm{~min}$. Spore pellets were suspended in $500 \mu l$ lysis buffer $(100 \mathrm{mM} \mathrm{NaCl}, 10 \mathrm{mM}$ Tris, $10 \mathrm{mM}$ EDTA, $0.2 \% \mathrm{SDS}$, and $0.4 \mathrm{mg}$ $\mathrm{ml}^{-1}$ Proteinase $\mathrm{K}$ ) and incubated at $55^{\circ} \mathrm{C}$ for 3 to $4 \mathrm{~h}$. DNA was then purified using the Miniprep Express Matrix (BIO 101, USA). A nested PCR system was used for amplification. DNA was amplified with the $18 \mathrm{e}-18 \mathrm{~g}$ ' universal primer pair. This was followed by a second round PCR with the MX5-MX3 primer pair or in some cases with SphF-Sph-R (Table 2). In both steps of the nested PCR, the total volume of the PCR reactions was $50 \mu \mathrm{l}$, which contained approx. 10 to $150 \mathrm{ng}$ DNA, 1× Taq PCR reaction buffer (MBI Fermentas), $1.25 \mathrm{mM}$ $\mathrm{MgCl}_{2}, \quad 0.2 \mathrm{mM}$ dNTP mix (Sigma), 50 pmol of each primer and 2 units of Taq DNA Polymerase (MBI Fermentas). 
Table 2. Primers used for PCR and/or sequencing

\begin{tabular}{|lll|}
\hline Name & Sequence & Source \\
\hline 18 e & 5'-CTG GTT GAT TCT GCC AGT-3' & Hillis \& Dixon (1991) \\
18g' & 5'-CGG TAC TAG CGA CGG GCG GTG TG-3' & Hillis \& Dixon (1991) \\
MX5 & 5'- CTG CGG ACG GCT CAG TAA ATC AGT-3' & Andree et al. (1999) \\
MX3 & 5'-CCA GGA CAT CTT AGG GCA TCA CAG A-3' & Andree et al. (1999) \\
MB5r & 5'-ACC GCT CCT GTT AAT CAT CAC C-3' & Eszterbauer (2004) \\
MB3f & 5'-GAT GAT TAA CAG GAG CGG TTG G-3' & Eszterbauer (2004) \\
MC5 & 5'-CCT GAG AAA CGG CTA CCA CAT CCA-3' & Molnár et al. (2002) \\
MC3 & 5'-GAT TAG CCT GAC AGA TCA CTC CAC GA-3' & Molnár et al. (2002) \\
SphF & 5'-ACT CGT TGG TAA GGT AGT GGC T-3' & Eszterbauer \& Székely (2004) \\
SphR & 5'-GTT ACC ATT GTA GCG CGC GT-3' & Eszterbauer \& Székely (2004) \\
\hline
\end{tabular}

MJ Research PTC-200 and Biometra T1 thermocycles were used for amplification. Amplification conditions in the first round were: $95^{\circ} \mathrm{C}$ for $50 \mathrm{~s}, 56^{\circ} \mathrm{C}$ for $50 \mathrm{~s}$ and $72^{\circ} \mathrm{C}$ for $80 \mathrm{~s}$ for 35 cycles, with a terminal extension at $72^{\circ} \mathrm{C}$ for $7 \mathrm{~min}$. This was followed in the second round with primers MX5 and MX3: $95^{\circ} \mathrm{C}$ for $30 \mathrm{~s}, 50^{\circ} \mathrm{C}$ for $30 \mathrm{~s}$ and $72^{\circ} \mathrm{C}$ for $60 \mathrm{~s}$ for 35 cycles, and was terminated with an extension period at $72^{\circ} \mathrm{C}$ for $7 \mathrm{~min}$. For PCR using SphF and SphR primers, the same condition was applied as for ones with the 18e-18g' primer pair. The PCR products were electrophoresed in $1.0 \%$ agarose gels (Sigma) in Tris-BorateEDTA (TBE) buffer and then purified with QIAquick Gel Extraction Kit (Qiagen).

For samples with an insufficient amount of amplified PCR product for direct DNA sequencing, purified DNA was cloned into a pGEM-T Vector System I (Promega) following the manufacturer's manual. Positive clones were selected using the blue-white colour screening method and confirmed by digestion with restriction enzyme MspI and then by sequencing with the universal pUC/M13 primer (Promega). Purified PCR products and/or at least 2 positive clones per sample were sequenced in both directions with primers listed in Table 2 using the ABI BigDye Terminator v3.1 Cycle Sequencing Kit with an ABI 3100 Genetic Analyzer automated DNA sequencer (Applied Biosystems). For sequence assembling, the STADEN Sequence Analysis Package version 2001.0 (Staden 1996) was used. DNA sequence similarities were calculated with the Sequence Identity Matrix of the software BioEdit.

Phylogenetic analyses. Nucleotide sequences were aligned with the software CLUSTAL W (Higgins et al. 1994) available online. The alignment was corrected manually using the GeneDoc sequence alignment editor program. Phylogenetic calculations were performed with PHYLIP v3.6a (Felsenstein 1997). The data were analysed with maximum likelihood (DNAML with a transversion/transition ratio 1:2, empirical base frequencies, one rate class for nucleotide substitution and global rearrangements) and distance matrix analysis (DNADIST using Kimura-2 parameter followed by FITCH with global rearrangements). Clade support was assessed with bootstrapping (100 replicates for maximum likelihood and 1000 replicates for the distance matrix method). Ceratomyxa shasta was chosen as an outgroup.

\section{RESULTS}

Eight Myxobolus species [M. cycloides Gurley, 1893; M. dujardini (Thélohan, 1892); M. ellipsoides Thélohan, 1892; M. muelleri Buetschli, 1882; M. muellericus sp. n.; $M$. pseudodispar Gorbunova, 1936; Myxobolus sp. 1; Myxobolus sp. 2] were found in the chub during the survey. Each species had a specific location within the fish host (Table 1). Measurements of Myxobolus spp. examined are listed in Table 3, while their molecular characterization is summarised in Table 4.

\section{Myxobolus cycloides Gurley, 1893 ex Leuciscus cephalus}

Large, white, round plasmodia were located in the connective tissue of the swimbladder. Ellipsoidal spores (Figs. 1a \& 2a) with an average size of $14.1 \times$ $10.4 \mu \mathrm{m}$ had a large intercapsular process, and corresponded to data described and depicted by Lom \& Dyková (1992).

Histology: The histology of this species was not studied in detail during this survey, as the morphological data we obtained corresponded in all respects to those described by Holzer \& Schachner (2002).

Molecular data: $18 \mathrm{~S}$ rDNA sequences of 5 Мyхоbolus cycloides samples examined were 99.9 to $100 \%$ similar to each other.

Remarks: The species was originally described from a systematically closely related cyprinid fish, Rutilus rutilus; therefore, its occurrence in chub is probable. 
Table 3. Morphological features and measurements (mean \pm SE, range in parentheses) of Myxobolus spp. found in chub

\begin{tabular}{|c|c|c|c|c|c|c|c|}
\hline & M. cycloides & M. dujardini & M. ellipsoides & M. muelleri & M. muellericus & $\begin{array}{l}\text { Myxobolus } \\
\text { sp. } 1\end{array}$ & $\begin{array}{l}\text { Myxobolus } \\
\text { sp. } 2\end{array}$ \\
\hline $\begin{array}{l}\text { Location } \\
\text { of plasmodia }\end{array}$ & Swimbladder & Gill filaments & Fins & Gill filaments & Gill lamellae & Intestinal wall & Gill filaments \\
\hline Spore shape & Ellipsoidal & Pyriform & Ellipsoidal & Ellipsoidal & Ellipsoidal & Ellipsoidal & Ellipsoidal \\
\hline Spore length $(\mu \mathrm{m})$ & $\begin{array}{c}14.1 \pm 0.43 \\
(13-15.2)\end{array}$ & $\begin{array}{c}11.5 \pm 0.4 \\
(11-12)\end{array}$ & $\begin{array}{l}11.72 \pm 0.9 \\
(10.5-13.5)\end{array}$ & $\begin{array}{c}9.83 \pm 0.24 \\
(9.5-10)\end{array}$ & $\begin{array}{c}9.7 \pm 0.25 \\
(9.5-10)\end{array}$ & $\begin{array}{c}15.41 \pm 0.63 \\
(15-16.5)\end{array}$ & $\begin{array}{c}9.75 \pm 0.75 \\
(9-11)\end{array}$ \\
\hline Spore width $(\mu \mathrm{m})$ & $\begin{array}{c}10.43 \pm 0.12 \\
(9.8-11.1)\end{array}$ & $\begin{array}{l}7.4 \pm 0.55 \\
(6.5-8)\end{array}$ & $\begin{array}{c}9.7 \pm 0.51 \\
(9-11)\end{array}$ & $\begin{array}{l}7.5 \pm 0.24 \\
(7.5-8)\end{array}$ & $\begin{array}{l}8.1 \pm 0.10 \\
(8-8.2)\end{array}$ & $\begin{array}{c}13.16 \pm 0.65 \\
(12.5-14)\end{array}$ & $\begin{array}{c}9.16 \pm 0.24 \\
(9-9.5)\end{array}$ \\
\hline Spore thickness $(\mu \mathrm{m})$ & $\begin{array}{l}7.61 \pm 0.57 \\
(7.2-8.5)\end{array}$ & $\begin{array}{l}7.1 \pm 0.47 \\
(6.5-7.3)\end{array}$ & $\begin{array}{c}6.9 \pm 0.53 \\
(6.3-7.2)\end{array}$ & $\begin{array}{c}5.2 \pm 0.24 \\
(5-5.5)\end{array}$ & $\begin{array}{c}5.05 \pm 0.09 \\
(5-5.2)\end{array}$ & $\begin{array}{l}7.9 \pm 0.6 \\
(7.3-8.7)\end{array}$ & $\begin{array}{c}5.33 \pm 0.49 \\
(5-6)\end{array}$ \\
\hline $\begin{array}{c}\text { Length of polar } \\
\text { capsules }(\mu \mathrm{m})\end{array}$ & $\begin{array}{l}5.2 \pm 0.23 \\
(4.1-6.5)\end{array}$ & $\begin{array}{c}5.5 \pm 0.47 \\
(5-6)\end{array}$ & $\begin{array}{c}4.77 \pm 0.26 \\
(4.5-5)\end{array}$ & $\begin{array}{c}4.6 \pm 0.51 \\
(4-5)\end{array}$ & $\begin{array}{c}4.13 \pm 0.22 \\
(4-4.5)\end{array}$ & $\begin{array}{c}5.79 \pm 0.62 \\
(5-6.5)\end{array}$ & $\begin{array}{c}4.25 \pm 0.26 \\
(4-4.5)\end{array}$ \\
\hline $\begin{array}{l}\text { Width of polar } \\
\text { capsules }(\mu \mathrm{m})\end{array}$ & $\begin{array}{c}3.36 \pm 0.5 \\
(3-4)\end{array}$ & $\begin{array}{c}2.3 \pm 0.44 \\
(2-3)\end{array}$ & $\begin{array}{l}2.6 \pm 0.1 \\
(2.5-2.7)\end{array}$ & $\begin{array}{c}3.6 \pm 0.5 \\
(3-4)\end{array}$ & $\begin{array}{l}2.2 \pm 0.26 \\
(2-2.5)\end{array}$ & $\begin{array}{c}4 \pm 0.3 \\
(3.5-4.5)\end{array}$ & $\begin{array}{l}2.8 \pm 0.29 \\
(2.2-3)\end{array}$ \\
\hline $\begin{array}{l}\text { Intercapsular process } \\
\text { length }(\mu \mathrm{m})\end{array}$ & 2 & - & - & 1 & 1 & 2 & - \\
\hline $\begin{array}{l}\text { Number of polar } \\
\text { filament coils }\end{array}$ & $6-7$ & 6 & 6 & $5-6$ & 6 & 6 & 6 \\
\hline
\end{tabular}

\section{Myxobolus dujardini (Thélohan, 1892) ex Leuciscus cephalus}

Large elongated plasmodia with several lateral buddings of Myxobolus dujardini could easily be observed in the gills with the unaided eye or under low magnification of a preparation microscope (Fig. 3). In most cases, there was simultaneous infection with 3 species. Besides plasmodia of $M$. dujardini with characteristic buddings, similar-sized elongated plasmodia of $M$. muelleri in the gill filaments and small round plasmodia of M. muellericus sp. $\mathrm{n}$. in the gill lamellae were

Table 4. Myxobolus spp. examined at DNA level. nd: no data

\begin{tabular}{|c|c|c|c|}
\hline Species & $\begin{array}{l}\text { No. of } \\
\text { replicates } \\
\text { sequenced }\end{array}$ & $\begin{array}{c}\text { Genetic } \\
\text { similarities } \\
(\%)\end{array}$ & $\begin{array}{l}\text { GenBank } \\
\text { accession numbers }^{\mathrm{a}}\end{array}$ \\
\hline $\begin{array}{l}\text { M. cycloides ex } \\
\text { Leuciscus cephalus }\end{array}$ & S & $99.9-100$ & DQ439810 \\
\hline $\begin{array}{l}\text { M. dujardini ex } \\
\text { Leuciscus cephalus }\end{array}$ & $S$ & $96.4-100$ & $\begin{array}{l}\text { M.d. \#1: DQ439803 } \\
\text { M.d. \#2-3: DQ439804 }\end{array}$ \\
\hline $\begin{array}{l}\text { M. ellipsoides ex } \\
\text { Leuciscus cephalus }\end{array}$ & us & $98.1-100$ & $\begin{array}{l}\text { M.e. \#1: DQ439812 } \\
\text { M.e. \#2-4: DQ439813 }\end{array}$ \\
\hline M. muelleri & 3 & $99.8-100$ & DQ439806 \\
\hline M. muellericus & 4 & $97.7-100$ & $\begin{array}{l}\text { M.mc. \#1: DQ439807 } \\
\text { M.mc. \#2-4: DQ439808 }\end{array}$ \\
\hline M. cyprinicola & 1 & nd & DQ439805 \\
\hline Myxobolus sp. 1 & 1 & nd & DQ439809 \\
\hline Myxobolus sp. 2 & 2 & 99.6 & DQ439811 \\
\hline
\end{tabular}

found (Fig. 4). Mature plasmodia of M. dujardini containing 150000 to 200000 spores were found at the end of July and in August.

Spores of M. dujardini (Figs. 1b \& 2b) had an average size of $11.54 \times 7.41 \mu \mathrm{m}$. They had oval or pear-shaped spores with an elongated body, conical anterior end and a rounded posterior end in frontal view. In sutural view, a protrusion emerged at the sutural region of the posterior end. Polar capsules were elongated. No iodinophilous vacuole was found in the sporoplasm.

Histology: Young plasmodia of Myxobolus dujardini started their development in the multilayered epithelium of the gill filaments (Fig. 5). Large elongated plasmodia of $M$. dujardini formed several lateral buddings in the epithelium. Plasmodia measuring 1.7 to $2 \mathrm{~mm} \times 0.2$ to $0.5 \mathrm{~mm}$ were mostly found at the non-lamellar edges of the filaments. (Fig. 3).

Molecular data: DNA sequences of 2 Myxobolus dujardini samples gave $100 \%$ identity, while a third sample collected from a similar characteristic plasmodium with a spore morphology typical of $M$. dujardini showed only $96.4 \%$ similarity to the other two. Morphologically similar species such as $M$. macrocapsularis, $M$. hungaricus and $M$. elegans were 78.1 to $78.4 \%, 93.2$ to $94.4 \%$ and 78.1 to $78.4 \%$ similar to $M$. dujardini, respectively. 

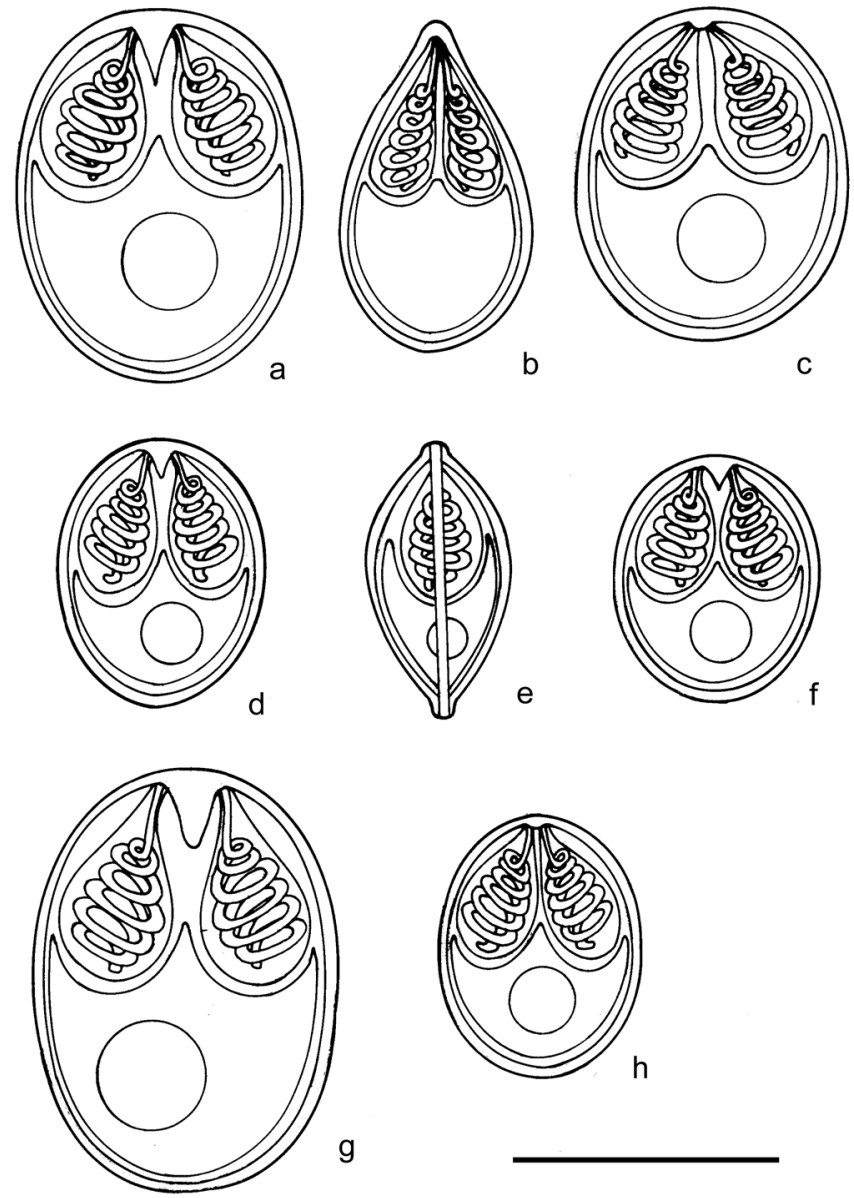

g

Fig. 1. Schematic drawings of spores of different Myxobolus spp. infecting chub. (a) M. cycloides, (b) M. dujardini, (c) $M$. ellipsoides, (d) M. muelleri, (e) M. muellericus sp. n. in sutural view, (f) $M$. muellericus sp. $\mathrm{n}$. in frontal view, (g) $M y x o-$ bolus sp. 1, (h) Myxobolus sp. 2. Scale bar $=10 \mu \mathrm{m}$

Remarks: Myxobolus dujardini was originally described from Scardinius erythrophthalmus and Rutilus rutilus. According to Lom (1961), this species frequently infects Leuciscus leuciscus and L. cephalus. We also regard this species as a common parasite of chub.

\section{Myxobolus ellipsoides Thélohan, 1892 ex Leuciscus cephalus}

Large, white, round plasmodia of this species were found in the fins. Spores measuring $11.7 \times 9.7 \mu \mathrm{m}$ on average from matured plasmodia showed an elliptical shape similar to spores of $M$. cycloides, but they had no intercapsular processes. Inside the sporoplasm, a large iodinophilous vacuole was observable (Figs. 1c \& 2c).

Histology: In histological sections, plasmodia were found in the connective tissue of the skin in duplicate between 2 cartilaginous fin rays. The ectoplasm of the plasmodium was bordered by a thin connective tissue layer (Fig. 6), and no connection was found between plasmodia and cartilaginous elements.

Molecular data: DNA sequences of 3 Myxobolus ellipsoides samples from different chub specimens showed $100 \%$ identity, while the fourth sample showed $98.1 \%$ similarity to the other 3 mentioned above.

Remarks: There is already a $18 \mathrm{~S}$ rDNA sequence of Myxobolus ellipsoides (collected from roach Rutilus rutilus) available in GenBank (AF085178). The similarity between this DNA sequence and the one sequenced in the present study is only $72.4 \%$. It is likely that species identified as $M$. ellipsoides from different cyprinids up to this time might cover several morphologically similar species. Spores of the species which we identified as $M$. ellipsoides were smaller than those described from the type host Tinca tinca. Until more detailed studies are performed, and most of all, until the comparative morphological and molecular study of $M$. ellipsoides originating from the type host is completed, we designate our species as M. ellipsoides ex Leuciscus cephalus.

\section{Myxobolus muelleri Bütschli, 1882}

Myxobolus muelleri Bütschli, 1882 is the first Myxobolus species described from Leuciscus cephalus. Large, cylindrical and elongated plasmodia of this species develop in the gill filaments. The relatively small, $9.7 \times 8.1 \mu \mathrm{m}$, oval or short ellipsoidal spores (Figs. 1d \& $2 \mathrm{~d})$ had a small but clearly visible intercapsular process, a small iodinophilous vacuole in the sporoplasm and a relatively wide suture.

Histology: Elongated plasmodia of Myxobolus muelleri, reaching a size of 1 to $1.5 \mathrm{~mm}$, were located in the lumen of the arteria afferens of the gill filaments (Fig. 7). The vascular location was clearly indicated by serum around the plasmodia and red blood cells in the uninfected part of the artery. After disruption of the mature plasmodium, spores were disseminated in the artery of the filaments and capillaries of the lamellae (Fig. 8), and were carried by the blood stream to different parts of the fish body.

Molecular data: The DNA sequences of spores obtained from 3 large $M$. muelleri plasmodia showed a 99.8 to $100 \%$ similarity.

Remarks: Myxobolus muelleri is one of the earliestknown Myxobolus species. The occurrence of this species has been mentioned from dozens of different fish species. It seems to be obvious that the majority of data concerning $M$. muelleri comes from misidentifications. Our opinion is that only those species could be identified as $M$. muelleri with certainty which are not only 

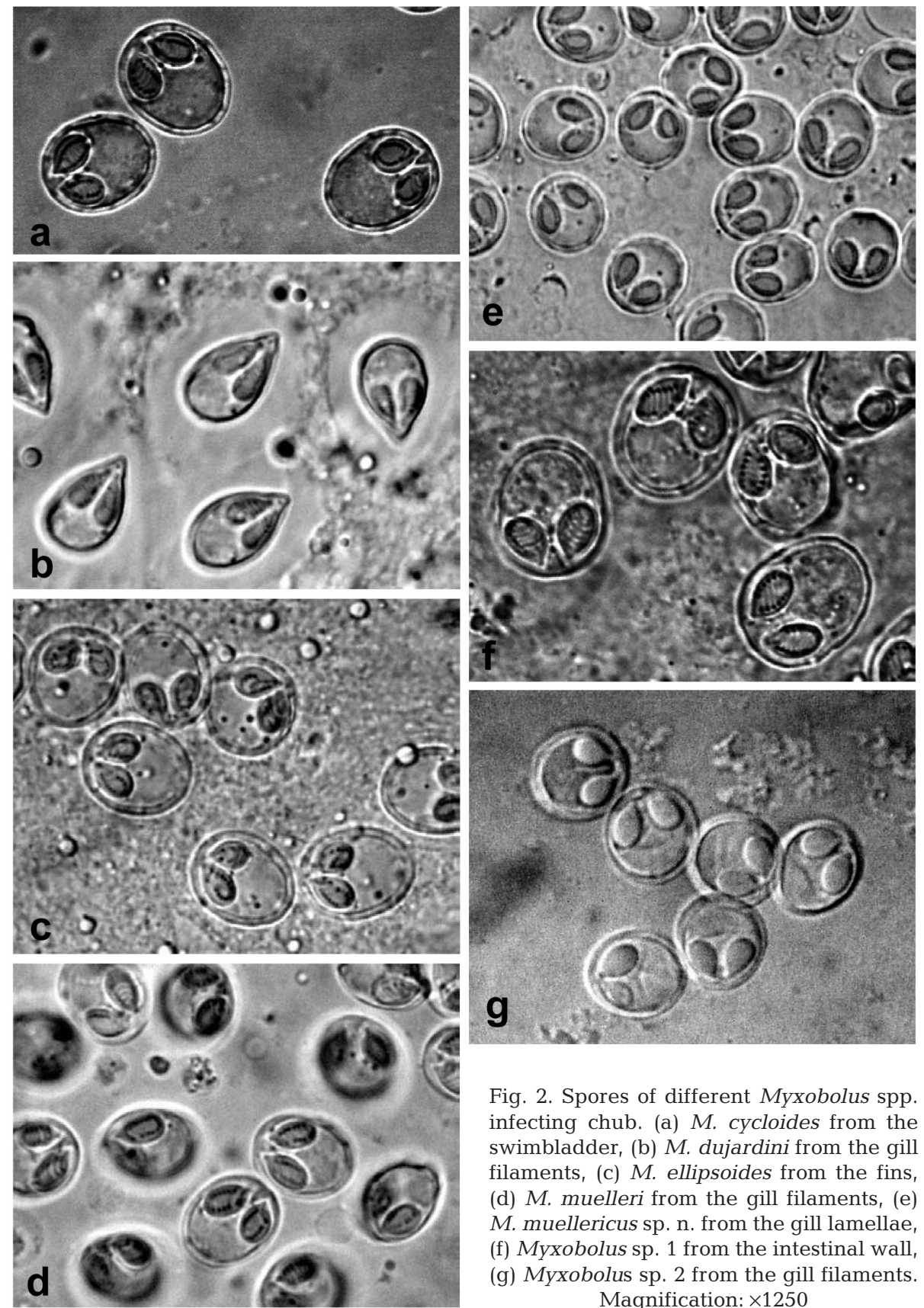

Fig. 2. Spores of different Myxobolus spp. infecting chub. (a) M. cycloides from the swimbladder, (b) M. dujardini from the gill filaments, (c) $M$. ellipsoides from the fins, (d) M. muelleri from the gill filaments, (e) M. muellericus sp. $\mathrm{n}$. from the gill lamellae, (f) Myxobolus sp. 1 from the intestinal wall, (g) Myxobolus sp. 2 from the gill filaments. Magnification: $\times 1250$

morphologically adequate but also infect the typical host Leuciscus cephalus and develop in the typical gill location. As chub is the typical host of M. muelleri, measurements and molecular data presented in the present paper may characterise this species. Three of our spore samples collected from large vascular cysts showed a close genetic relationship, while a M. muelleri species collected from the same location in Hungary and studied at DNA level by Eszterbauer (2004) previously showed only a 97.3 to $97.4 \%$ similarity to the ones at hand. It is also remarkable that a morpho- logically rather similar species, $M$. bramae (AF507968), also studied by Eszterbauer (2004), showed a 98.4\% genetic similarity to the $M$. muelleri species examined. There is another 18S rDNA sequence of $M$. muelleri available in GenBank, from a species which was collected from Mugil cephalus by Bahri et al. (2003) (AY129314). Although this DNA sequence is $99.81 \%$ similar to the one of $M$. exiguus from the same fish host (AY129317), there is only a $70.8 \%$ similarity between the $M$. muelleri DNA sequence obtained by Bahri et al. (2003) and the one at hand. 

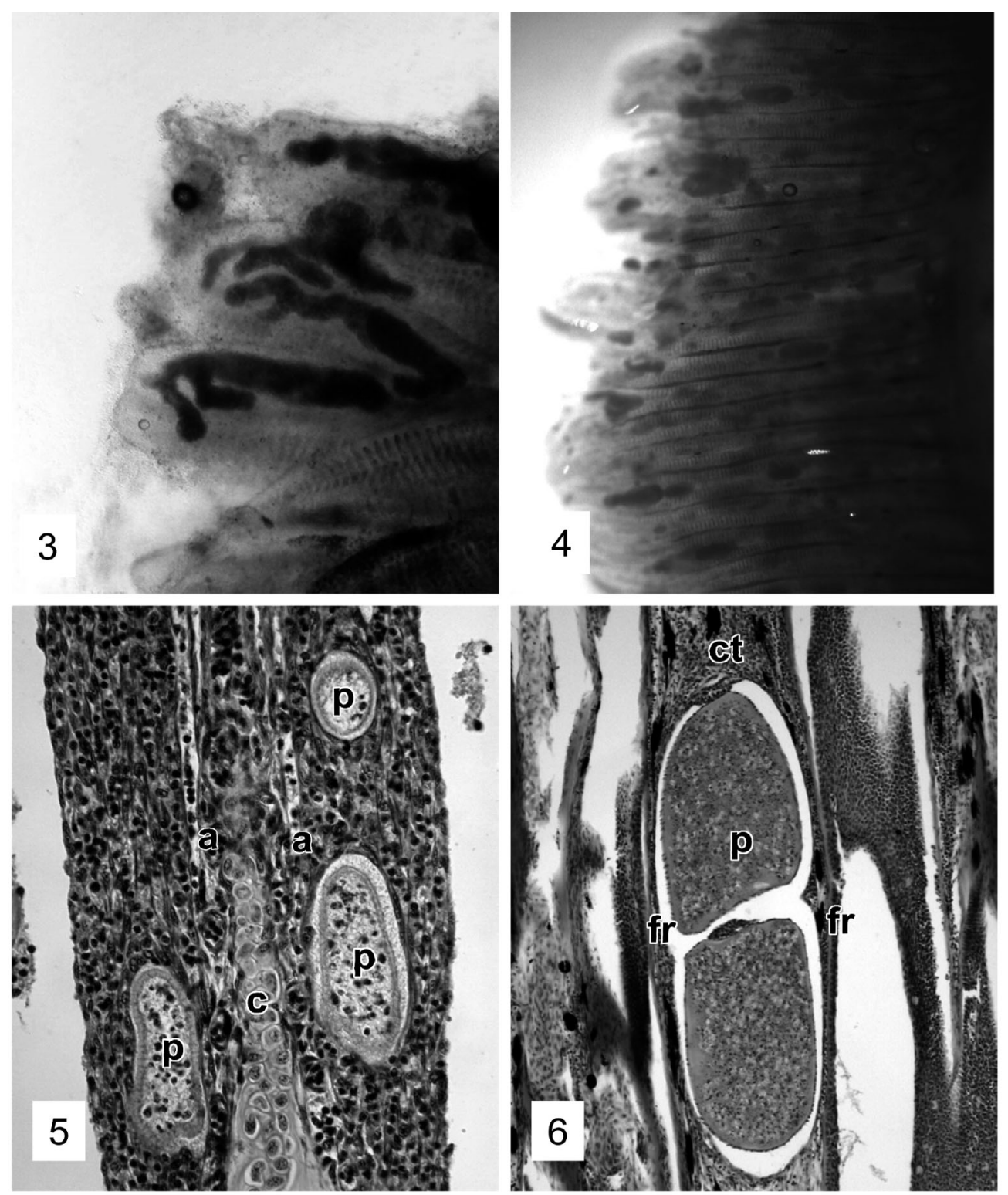

Figs. 3 to 6. Myxobolus spp. infecting chub. Fig. 3. M. dujardini infection in the gill filaments. Large plasmodia with lateral blebs located close to the tips of filaments. Fresh $\overline{\text { mount }}, \times 40$. Fig. 4 . Heavy infection of the gills with plasmodia of $M$. dujardini, $M$. muelleri and $M$. muellericus spp. Fresh mount, $\times 20$. Fig. 5. Young $M$. dujardini plasmodia (p) in the multilayered epithelium of a gill filament. Plasmodia are located in the non-lamellar part of the filament beside the artery (a) and the cartilaginous gill ray (c). Histological section. Haematoxylin and eosin ( $\mathrm{H} \& \mathrm{E}), \times 400$. Fig. 6. M. ellipsoides plasmodium (p) in the fin. The plasmodium is located in the connective tissue of the fin (ct), between 2 fin rays (fr). Histological section. H \& E, $\times 200$

\section{Myxobolus muellericus sp. $\mathbf{n}$.}

Type host: Leuciscus cephalus L.

Site of infection: Small plasmodia in the capillary network of gill lamellae on gill filaments.

Locality: The River Danube north of Budapest, Hungary.

Type material: Syntype spores in glycerine-gelatine were deposited in the parasitological collection of the
Zoological Department, Hungarian Natural History Museum, Budapest, Coll. No. HNHM-17649. The 18S rDNA sequence of Myxobolus muellericus was deposited in GenBank under the accession number DQ439808.

Etymology: The name of this species was composed from the name Myxobolus muelleri, a morphologically similar species of chub.

Description (based on 25 spores): Vegetative stages 

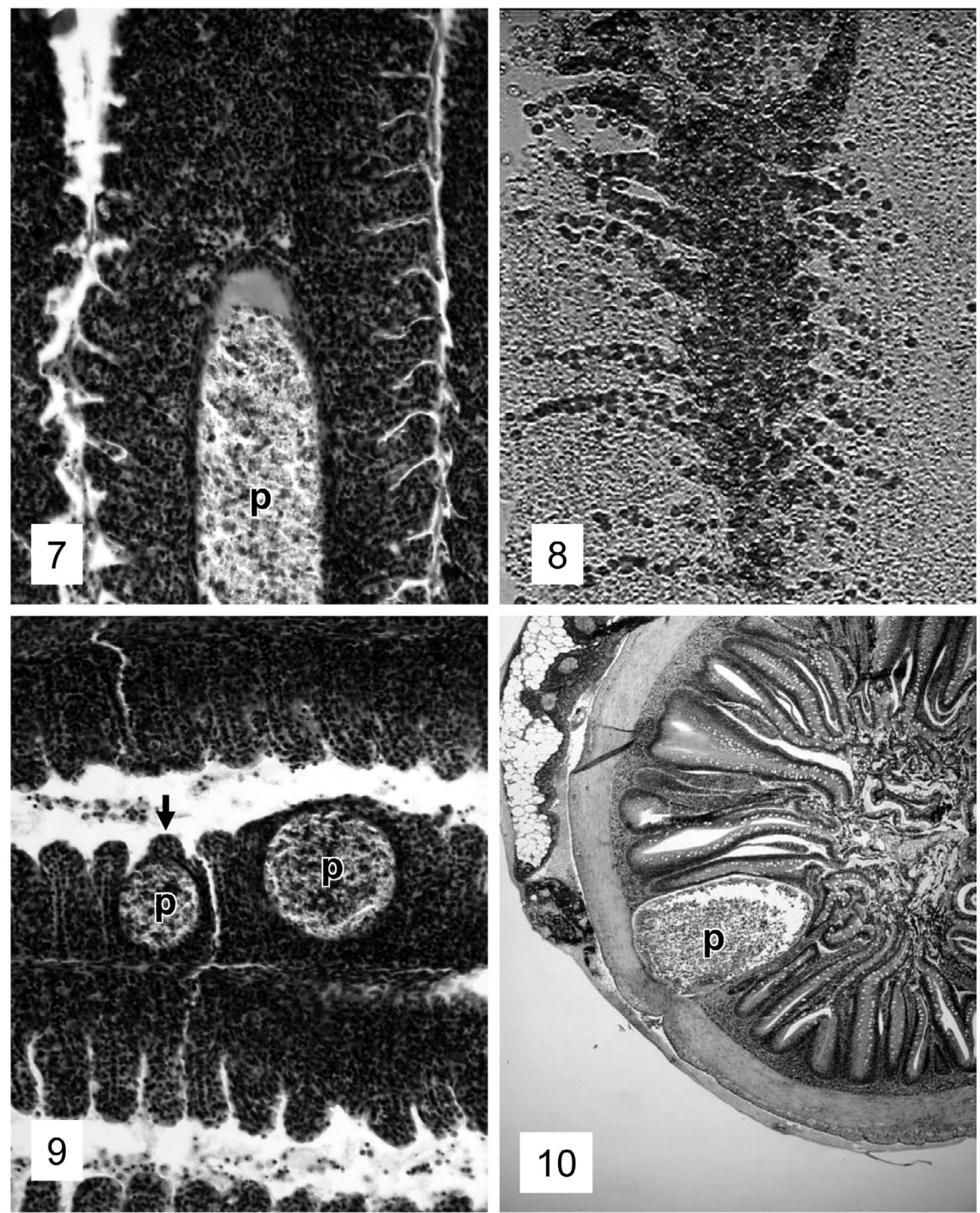

Figs. 7 to 10. Myxobolus spp. infecting chub. Fig. 7. Large plasmodium of M. muelleri (p) inside the lumen of the arteria afferens in a gill filament. Histological section. H \& E, ×200 Fig. 8. Spores of M. muelleri disseminated in the gill artery and capillaries of a lamella after the rupture of a mature plasmodium. Unstained preparation, $\times 200$. Fig. 9. Plasmodia (p) of M. muellericus sp. n. in the gill lamellae. Over the smaller plasmodium the tip of the lamella (arrow) can still be observed. Histological section. H \& E, $\times 200$. Fig. 10. Large plasmodium (p) of Myxobolus sp. 1 in the propria layer of the intestinal wall. Histological section. H \& E, $\times 50$

were round or short ellipsoidal plasmodia measuring 60 to $180 \mu \mathrm{m}$ in diameter inside gill lamellae (Fig. 9).

Spores were short ellipsoidal or roundish in frontal view (Figs. 1f \& 2e) and lemon-shaped in sutural view (Fig. 1e). Sutural line indistinct. Sutural edge moderately protruding. Valves thin, symmetrical and smooth without distinct edge markings. Spores $9.7 \pm 0.25(9.5$ to 10 ) $\mu \mathrm{m}$ long, $8.1 \pm 0.10$ (8 to 8.2 ) $\mu \mathrm{m}$ wide and 5.05 \pm 0.09 (5 to 5.2) $\mu \mathrm{m}$ thick. Two polar capsules were pyriform, nearly equal in size, $4.13 \pm 0.22$ (4 to 4.5 ) $\mu \mathrm{m}$ long and $2.2 \pm 0.26$ ( 2 to 2.5 ) $\mu \mathrm{m}$ wide, tapering toward the discharging canals of the polar filaments. Polar filaments coiled with 6 turns in the polar capsule, situated perpendicularly to the longitudinal axis of the capsule. Spore with a long triangular intercapsular appendix at the anterior end. Sporoplasm nuclei 
indiscernible; a small iodinophilous vacuole found in the sporoplasm.

Spores obtained from small lamellar plasmodia (Fig. 2e) were morphologically indistinguishable from spores obtained from large cysts (Table 1).

Histology: Small, round plasmodia developed in the capillary network of gill lamellae. Plasmodia filled most of the capillary network of the lamellae. Capillaries were only visible along the border of plasmodia and in the unaffected lamellar tip (Fig. 9). The multilayered epithelium between neighbouring lamellae was compressed, and the neighbouring lamellae were pushed aside.

Molecular data: 18S rDNA sequences of 3 Myxobolus muellericus samples were 99.7 to $100 \%$ identical, while a fourth sample showed only $97.9 \%$ similarity to the other 3.

Remarks: On the basis of spore morphology, Myxobolus muellericus sp. n. seems to be identical with $M$. muelleri. The 2 species, however, clearly differ in location of plasmodia in the gills and in their $18 \mathrm{~S}$ rDNA. Large plasmodia of $M$. muelleri develop in the artery of gill filaments, while $M$. muellericus forms small plasmodia in the capillary network of gill lamellae. At the DNA level, the similarity between the 2 species was only $88.0 \%$.

\section{Myxobolus pseudodispar Gorbunova, 1936 ex Leuciscus cephalus}

Large, elongated plasmodia of Myxobolus pseudodispar in muscle cells of chub were found in practically every specimen examined (Table 1). Finding disseminated spores in melanomacrophage centres of the renal parenchyma was the easiest way of demonstrating infection of this species. Spores found in the chub corresponded morphologically to those found in the same locations in other leuciscine cyprinids (Molnár et al. 2002). Holzer \& Schachner (2001), who identified this species as $M$. cyprini, made a detailed study on the spores of this species trapped in macrophage centres. DNA studies were not performed.

\section{Myxobolus sp. 1}

Large round or ellipsoidal plasmodia of this species (Fig. 10) could easily be observed in the opened intestine with the unaided eye or at low magnification of the preparation microscope. They were located disseminated in the first part of the gut. Large ellipsoidal spores of this species (Figs. 1g \& 2f) resembled Myxobolus cycloides, but they were more symmetrical and larger $(15.41 \times 13.16 \mu \mathrm{m})$. This species resembled both in plasmodial location and spore morphology to M. cyprinicola Reuss, 1906, a parasite of Cyprinus carpio.

Histology: Plasmodia were located in the intestinal wall inside the submucosa and propria above the muscular layer (Fig. 10). Although only developed plasmodia were found, it is likely that development of the plasmodium starts in a capillary located inside the connective tissue.

Molecular data: The DNA sequence of a single sample of this species was rather different from the morphologically very similar Myxobolus cyprinicola species. The genetic similarity of the 2 species was $86.7 \%$. DNA sequences of this species also differed from sequences of other Myxobolus species collected from chub. The most closely related species was $M$. cycloides with $96.9 \%$ similarity in their 18S rDNA fragment.

Remarks: This species resembled both in spore morphology and location of plasmodia Myxobolus cyprinicola Reuss, 1906 from the common carp, but the spores of $M$. cyprinicola were smaller. Despite morphological similarities and identical location, the 2 species clearly differ at the DNA level. If the molecular examination of further samples confirms these findings, this parasite can be described as novel.

\section{Myxobolus sp. 2}

Less frequently, spores (Figs. $1 \mathrm{~h} \& 2 \mathrm{~g}$ ) about the size of Myxobolus muelleri were found in large vascular, intrafilamental plasmodia in gills. Spores of this species differed from the typical $M$. muelleri spores by having no or only a very small indistinct intercapsular process between the polar capsules. By lacking distinct intercapsular processes, spores resembled the ones of M. ellipsoides, although they were smaller in size. The species needs more attention in the future, as due to its similar size and location in gills, it might encumber diagnosis of the species $M$. muelleri and $M$. mullericus sp. n.

Molecular data: Two samples were sequenced that showed $99.6 \%$ similarity in $18 \mathrm{~S}$ rDNA. The morphologically similar Myxobolus muelleri and M. muellericus sp. n. differed from Myxobolus sp. 2 at DNA level (88.9 to $89.6 \%$ and 89.8 to $90.1 \%$ similarity, respectively). Genetically, the most closely related species was $M$. ellipsoides (94.4 to $94.7 \%$ ).

Remarks: The species differs from Myxobolus muelleri and $M$. muellericus sp. n. by lacking an intercapsular process in its spores and also in its $18 \mathrm{~S}$ rDNA. After morphological and molecular examination of further samples, this parasite could be described as novel. 


\section{PCR, DNA sequencing and phylogenetic analyses}

The universal $18 \mathrm{e}-18 \mathrm{~g}$ ' primers, the primer pair MX5-MX3 and SphF-SphR, successfully amplified approx. 1900, 1600 and $1400 \mathrm{bp}$ fragments of the $18 \mathrm{~S}$ rDNA from every sample examined, respectively. The 23 samples sequenced belonged to 8 well-distinguishable Myxobolus species, of which 6 have not been studied at the DNA level previously. 18S rDNA sequences obtained were deposited in GenBank under the accession numbers listed in Table 4.

Phylogenetic analyses were performed on the basis of a 1609 bp long final edited alignment that contained 43 DNA sequences. The distance matrix analysis confirmed the clustering pattern of the maximum likelihood analysis (Fig. 11). Replicates of every Myxobolus spp. examined grouped together. DNA sequences of M. ellipsoides (AF085178), M. bramae (AF085177) and M. muelleri (AY129314) studied by Andree et al. (1999) and Bahri et al. (2003), respectively, were located distant from the ones examined in the present study.

\section{DISCUSSION}

Myxobolus species infecting chub are excellent subjects for studying species specificity and site selection on a morphological basis and by molecular methods. According to the results of the present studies, chub specimens collected from the same habitat may be infected by at least 8 different Myxobolus species at the same time, and the majority of these species differ from one another in intrapiscine location and morphological appearance. In addition to the comparison of species infecting chub, comparisons with species that are morphologically very similar or completely identical but that infect other fish species are also possible. Various authors have suggested the occurrence of certain Myxobolus species in a strikingly large number of hosts. After summarising their data, Donec \& Shulman (1984), for example, indicated 79 European and American cyprinids as hosts of the species $M$. muelleri originally described from chub. These data are obviously wrong and require corrections with respect to both the number of hosts and locations. In the present work, we could unquestionably identify the species $M$. muelleri described from chub and detectable only from the gills, and we regard its $18 \mathrm{~S}$ rDNA sequence as valid. Similarly, we consider it likely that Myxobolus species described from the closely related roach Rutilus rutilus may also parasitise the chub. Therefore, M. cycloides, $M$. pseudodispar and $M$. dujardini are discussed as parasites common to the 2 fish species above and are labelled with the attribute 'ex Leuciscus cephalus'. The spores collected from the typical swimbladder location are unambiguously identified as spores of $M$. cycloides.

Identification of the species M. ellipsoides appears to be much more problematic. Despite their smaller dimensions, the spores collected from the plasmodium developing in the fin morphologically correspond to the type described from the original host, the tench Tinca tinca; however, because of the phylogenetic distance between the hosts and the differences existing in the data already available in GenBank, unambiguous identification is problematic. Despite these differences, the parasite found is identified as the species $M$. ellipsoides until spores yet to be collected from the type host are studied. However, in order to distinguish them from the species described by Andree et al. (1999) from $R$. rutilus, the DNA sequences deposited in GenBank are designated with the attribute 'ex Leuciscus cephalus'.

Myxobolus dujardini (Thelohan, 1892) is one of the longest known Myxobolus species. The parasite was described by Thélohan (1892) from rudd Scardinius erythrophthalmus and roach Rutilus rutilus under the name Myxosoma dujardini. As the sporoplasm of its spores does not contain an iodinophilous vacuole, Shulman (1966) also classified this parasite into the genus Myxosoma; however, Landsberg \& Lom (1991) placed it into the genus Myxobolus. Lom (1961), who provided the first detailed description and illustration of the species, illustrated 2 morphologically similar but somewhat different spore forms that he regarded as being typical of the dace Leuciscus leuciscus and the chub Leuciscus cephalus, respectively. As regards their dimensions and shape, the myxospores we found were fully identical with the species described by Lom (1961) from chub but differed in their larger spore sizes from the species reported from dace and considered typical by Shulman (1966). Until the identity or difference of the 2 spore types is confirmed by molecular studies, we identify the species we collected from chub and experimentally studied as the species Myxobolus dujardini (Thelohan, 1892). This species appears to be a common parasite of chub in the River Danube, as its presence could be demonstrated on the gills of 31 out of the 87 specimens examined. Despite this fact, collection of spores intended for infection experiments and molecular studies was rather difficult; namely, because of the high prevalence of 3 other Myxobolus species, M. dujardini spores free of contamination could be collected from only a few fish specimens.

The characteristic location of Myxobolus dujardini in the gill filaments was previously suggested by Dogiel (1932), who, based on a histological picture of a massive infection, described the same location of plasmodia as we observed in the present study. 


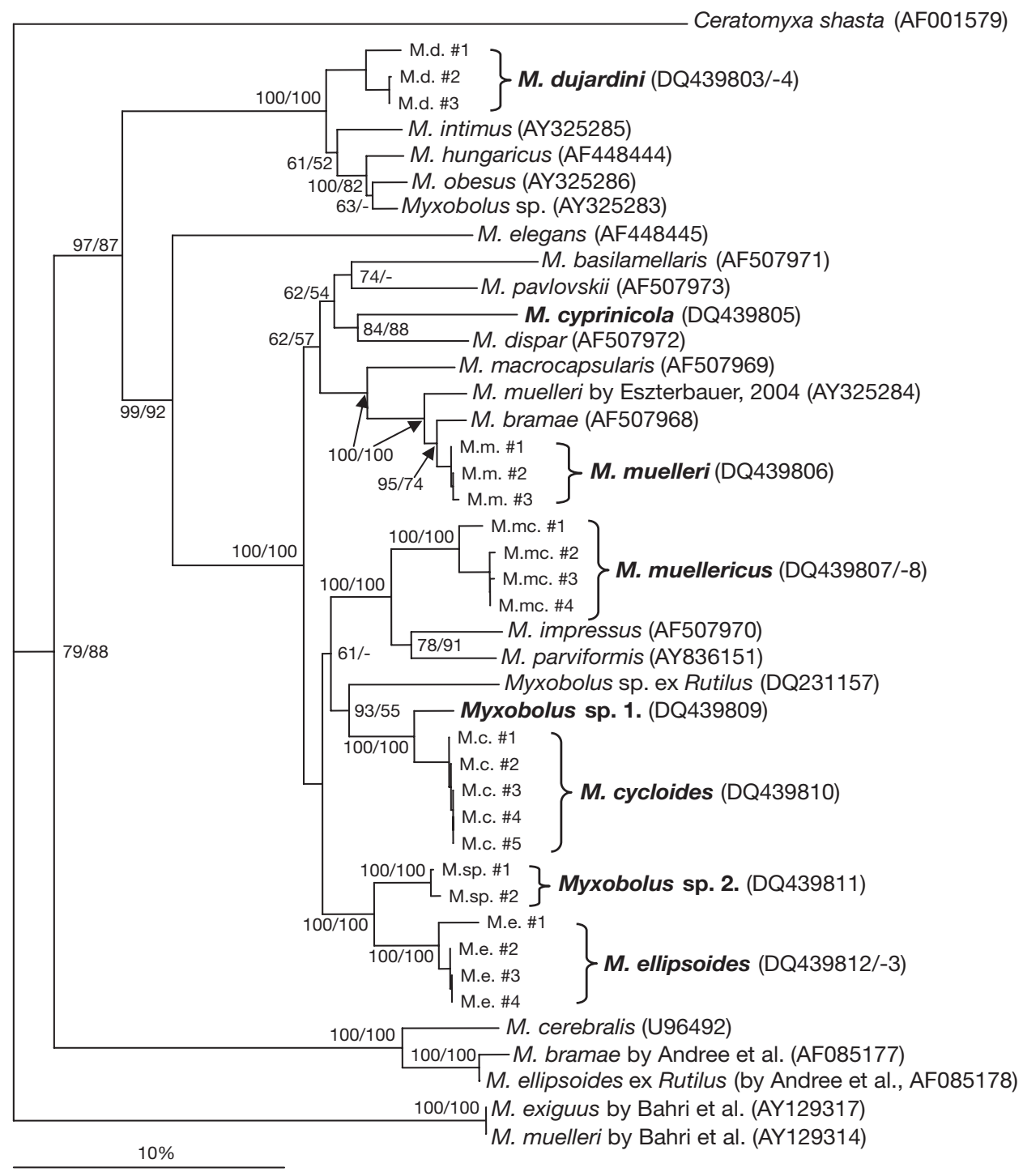

Fig. 11. Phylogenetic tree generated by distance matrix and maximum likelihood analyses of the 18S rDNA sequences of myxosporeans, rooted at Ceratomyxa shasta. Numbers at nodes indicate bootstrap confidence levels in percent (distance matrix method: 1000 repetitions; maximum likelihood: 100 repetitions, transversion/transition 1:2). GenBank accession numbers given in parentheses. Distance scale is shown beside the tree. Myxosporeans examined in the present study are in bold. M.d.: Myxobolus dujardini; M.m.: M. muelleri; M.mc.: M. muellericus; M.c.: M. cycloides; M.e.: M. ellipsoides

Very often the plasmodia of Myxobolus muelleri, $M$. muellericus sp. n. and the species designated by us as Myxobolus sp. 2 occurred on the gills in the form of mixed infection with $M$. dujardini. While the plasmodia of M. dujardini, designated by Molnár (2002a) as being of epithelial type, always developed in the multilayered, lamella-free epithelium of the gill filaments, M. muelleri, Myxobolus sp. 2 and M. muellericus proved to be of the vascular type, since the plasmodia of M. muelleri and Myxobolus sp. 2 produced elongated cysts of substantial size in the arteries of the gill filaments, whereas $M$. muellericus was found to infect the gill lamellae in the form of small round plas- modia. The spores of the last 3 species did not differ from one another in shape and size, and the species $M$. muelleri and $M$. muellericus sp. n. could be distinguished from each other only by their typical location and their differences at the DNA level. Although identical in terms of size and location, Myxobolus sp. 2 differed from the typical $M$. muelleri species by the absence of the characteristic triangular intercapsular process from its spores, and phylogenetically it was also closer to $M$. ellipsoides, a species similarly lacking an intercapsular process.

The results presented above support the observations reported by Molnár (1994, 2002a,b), Holzer \& 
Schachner (2002), Cone \& Marcogliese (2004), Cone et al. (2004) and Kallert et al. (2005) and suggest that indication of the typical location is indispensable for the precise identification of species. In the present study, the plasmodia of Myxobolus dujardini developing in the epithelium of the gill filaments were easily distinguishable from the plasmodia of $M$. muelleri developing in the gill arteries, even in the case of mixed infection. The molecular findings also prove that M. muellericus sp. $\mathrm{n}$., developing in the capillary network of the gill lamellae but having spores resembling those of M. muelleri, is a distinct species, which can be distinguished on the basis of its typical location from the species M. muelleri, which forms large plasmodia in the arteries of the gill filaments. Differentiation is encumbered especially by the fact that the species Myxobolus sp. 2, which is the same size but lacks an intercapsular process, developed in the same location as $M$. muellericus, a species of the same size but one which has a large intercapsular process in its spores.

The relatively high diversity of spores identified as Myxobolus muelleri was previously observed by Donec \& Tozyjakova (cit. Donec \& Shulman 1984), who used the slightly more elongated polar capsules as the basis for distinguishing the species $M$. muelleriformis Donec et Tozyjakova, 1984 from M. muelleri and $M$. bramae which were the same size and had the same spore morphology. The above authors listed 11 cyprinid species as hosts of $M$. muelleriformis; these species, however, did not include the chub. We cannot identify the species we found as $M$. muelleriformis and the findings of the present study lead us to conclude that, like the species M. muelleri, this species will also prove to be a collective species after detailed molecular studies.

Myxobolus sp. 1, a species which has relatively large spores, resembles $M$. cyprinicola as regards its location. This parasite also resembles $M$. cycloides with respect to the shape and dimensions of its spores but can easily be differentiated from the above 2 species at the DNA level, and further molecular data will probably allow its description as a new species.

The occurrence of Myxobolus pseudodispar in leuciscine fishes was studied in detail by Molnár et al. (2002). Although their above-cited paper does not contain data on chub, in the present survey only the occurrence of this parasite in the chub was recorded and no other studies were done.

The Myxobolus species parasitising chub and studied in this work were characterised by relatively strict site specificity, and each species could always be collected from its characteristic location. There was only a single exception to this rule, i.e. when the spores of $M$. muelleri, generally regarded as a gill parasite, were detected both morphologically and on the basis of the
18S rDNA from plasmodia developing in the swimbladder. It goes without question that tissue specificity is more important than site specificity, as also demonstrated by the studies of Cone \& Easy (2005), who detected the plasmodia of the species $M$. diaphanus in the connective tissues of different organs of Fundulus diaphanus.

When compared with the GenBank-deposited sequences of some major Myxobolus species of cyprinids and of the salmonid parasite $M$. cerebralis, the molecular data obtained on the Myxobolus species parasitising chub allow us to draw very interesting conclusions. Their position on the phylogenetic tree shows that the Myxobolus species detected from cyprinids are genetically markedly different from the species M. cerebralis, a parasite of salmonids. At the same time, a Myxobolus species infecting cyprinids, M. dujardini, which has pear-shaped spores, is genetically markedly distinct from the Myxobolus species parasitising chub, which mostly have round or elliptical spores. It shows relatedness to the species which have a similar spore morphology as $M$. hungaricus, $M$. obesus and M. intimus. It seems that minor morphological characteristics such as the presence of an intercapsular process between the 2 polar capsules can also be reflected in relationships among species. Myxobolus sp. 1, a larger species which lives in different organs and possesses an intercapsular process, shows genetic relatedness to $M$. cycloides, a species which also has an intercapsular process of substantial size, while the gill-parasitic Myxobolus sp. 2, which possesses no intercapsular process, is closely related to M. ellipsoides, which is substantially larger but has a similar spore. Within groups containing morphologically similar species, differences in tissue location are reflected in molecular differences. It is no mere chance that the species M. muelleri, which forms plasmodia in the arteries of gill filaments, is more closely related to the species occurring in a similar location within the host (as M. bramae and M. macrocapsularis from bream and $M$. dispar from carp) than to M. muellericus, a species which has an identical morphology but which forms plasmodia in the gill lamellae. These findings are consistent with the theory suggested by Eszterbauer (2004) that there is a correlation between tissue specificity and genetic relationships among Myxobolus spp., and they also show the importance of the detection of tissue location for in the exact description and identification of myxosporean species.

Acknowledgements. The present study was supported by the Hungarian Scientific Research Fund (OTKA, projects no. T.042464 and F045908) and by a fisheries fund of the Ministry of Agriculture and Regional Development. The author thanks Ms. Györgyi Pataki for preparing drawings and histological slides. 


\section{LITERATURE CITED}

Andree KB, Székely Cs, Molnár K, Gresoviac SJ, Hedrick RP (1999) Relationships among members of the Genus Myxobolus (Myxozoa: Bivalvidae) based on small subunit ribosomal RNA sequences. J Parasitol 85:68-74

Bahri S, Andree KB, Hedrick RP (2003) Morphological and phylogenetic studies of marine Myxobolus spp. from mullet in Ichkeul Lake, Tunisia. J Eukaryot Microbiol 50: 463-470

Blazer VS, Densmore CL, Schill WB, Cartwright DD, Page SJ (2004) Comparative susceptibility of Atlantic salmon, lake trout and rainbow trout to Myxobolus cerebralis in controlled laboratory exposures. Dis Aquat Org 58:27-34

Cone DK, Easy RH (2005) Supplemental diagnosis and molecular taxonomy of Myxobolus diaphanus (Fatham, Porter et Richardson, 1940) (Myxozoa) parasitizing Fundulus diaphanus (Cyprinodontiformes) in Nova Scotia, Canada. Folia Parasitol 52:217-222

Cone D, Marcogliese DJ (2004) Remodelling of mixed bone during infections of Myxobolus scleroperca (Myxozoa) in Percina caproides (Rafinisque) (Percidae) from the St. Lawrence River, Quebec. J Fish Dis 27:551-554

Cone D, Marcogliese DJ, Russel R (2004) The myxozoan fauna of the spottail shiner in the Great Lakes basin: membership, richness, and geographical distribution. J Parasitol 90:921-932

Dogiel VA (1932) Parasitic diseases of fishes. Publ Selkhozgiz Leningrad, p 151 (in Russian)

Donec ZS, Shulman SS (1984) Knidosporidii (Cnidosporidia). In: Bauer ON (ed) Key to the parasites of freshwater fishes of the USSR, Vol 1. Nauka, Leningrad, p 88-251 (in Russian)

Eiras JC, Molnár K, Lu YS (2005) Synopsis of the genus Myxobolus Bütschli, 1882 (Myxozoa: Myxosporea: Myxobolidae). Syst Parasitol 61:1-46

El-Matbouli M, Hoffmann RW, Schoel H, McDowell TS, Hedrick RP (1999) Whirling disease: host specificity and interaction between the actinosporean stage of Myxobolus cerebralis and rainbow trout Oncorhynchus mykiss. Dis Aquat Org 35:1-12

Eszterbauer E (2004) Genetic relationship among gill-infecting Myxobolus species (Myxosporea) of cyprinids: molecular evidence of importance of tissue-specificity. Dis Aquat Org 58:35-40

Eszterbauer E, Székely Cs (2004) Molecular phylogeny of the kidney-parasitic Sphaerospora renicola from common carp (Cyprinus carpio) and Sphaerospora sp. from goldfish (Carassius auratus auratus). Acta Vet Hung 52:469-478

Felsenstein J (1997) PHYLIP-Phylogeny inference package v3.6a. Distributed by the University of Washington, Seattle, WA

Higgins D, Thompson J, Gibson T, Thompson JD, Higgins DG, Gibson TJ (1994) CLUSTAL W: improving the sensitivity of progressive multiple sequence alignment through sequence weighting, position-specific gap penalties and weight matrix choice. Nucl Acids Res 22:4673-4680

Hillis DM, Dixon T (1991) Ribosomal DNA: molecular evolu-

Editorial responsibility: Dieter Steinhagen,

Hannover, Germany tion and phylogenetic inference. Q Rev Biol 66:411-453

Hoffman GL (1999) Parasites of North American freshwater fishes, 2nd edn. Comstock Publishing Associates, Ithaca, NY

Holzer A, Schachner O (2001) Myxosporea and macrophage centers in chub (Leuciscus cephalus) - quantitative interaction seems to be focused on Myxobolus cyprini. Parasitology 122:53-62

Holzer A, Schachner O (2002) Myxobolus cycloides on the swimbladder of chub Leuciscus cephalus: a controlled, host-specific localisation. Dis Aquat Org 49:179-183

Kallert DM, Eszterbauer E, Erséus C, Haas W, El-Matbouli M (2005) Life cycle studies of Myxobolus parviformis sp. $\mathrm{n}$. (Myxozoa, Myxobolidae) from bream. Dis Aquat Org 66: 233-243

Kent ML, Andree KB, El-Matbouli M, Bartholomew JL and 12 others (2001) Recent advances in our knowledge on Myxozoa. J Eukaryot Microbiol 48:395-413

Landsberg JJ, Lom J (1991) Taxonomy of the genera of the Myxobolus/Myxosoma group (Myxobolidae: Myxosporea), current listing of species and revision of synonyms. Syst Parasitol 18:165-186

Lom J (1961) Protozoan parasites found in Czechoslovakian fishes I. Folia Zool 10:45-56

Lom J, Dyková I (1992) Protozoan parasites of fishes. Developments in aquaculture and fisheries science, Vol 26. Elsevier, Amsterdam

Lom J, Dyková I (1995) Myxosporea. In: Woo PTK (ed) Fish diseases and disorders, Vol. 1. Protozoan and metazoan infections. Cambridge University Press, Cambridge, p 97-148

Longshaw M, Frear P, Feist SW (2003) Myxobolus buckei sp n. (Myxozoa), a new pathogenic parasite from the spinal column of three cyprinid fishes from the United Kingdom. Folia Parasitol 50:251-262

Molnár K (1994) Comments on the host, organ and tissue specificity of fish myxosporeans and on the types of their intrapiscine development. Parasit Hung 27:5-20

Molnár K (2002a) Site preference of myxosporeans in the gill. Dis Aquat Org 48:197-207

Molnár K (2002b) Site preference of myxosporean spp. on the fins of some Hungarian fish species. Dis Aquat Org 52: $123-128$

Molnár K, Eszterbauer E, Székely C, Dán Á, Harrach B (2002) Morphological and molecular biological studies on intramuscular Myxobolus spp. of cyprinid fish. J Fish Dis 25: 643-652

Shulman SS (1962) Phylum Protozoa. In: BykhovskayaPavlovskaya IE, Gusev AV, Dubinina MN, Izjumova NA and 5 others (eds) Key to parasites of freshwater fishes of the USSR, No. 80. Nauka, Leningrad, p7-151 (in Russian)

Shulman SS (1966) Myxosporidia of the fauna of the USSR. Nauka, Moscow (in Russian)

Staden R (1996) The Staden Sequence Analysis Package. Mol Biotechnol 5:233-241

Thélohan P (1892) Observation sur les myxosporidies et essai de classification de ces organismes. Bull Soc Philomat Paris 4:165-178

Submitted: March 15, 2006; Accepted: August 1, 2006

Proofs received from author(s): November 7, 2006 